Article

\title{
Effects of Chemical and Solar Soil-Disinfection Methods on Soil Bacterial Communities
}

\author{
Cuixia Yun 1,2, Enke Liu ${ }^{1,2}$, Massimo Rippa ${ }^{3}$, Pasquale Mormile ${ }^{3}$, Dongbao Sun ${ }^{1,2}$, \\ Changrong Yan ${ }^{1,2, *}$ and Qin Liu ${ }^{1,2, *}$ \\ 1 Institute of Environment and Sustainable Development in Agriculture, Chinese Academy of Agricultural \\ Sciences, Beijing 100081, China; yuncuixia2020@163.com (C.Y.); liuenke@caas.cn (E.L.); \\ sundongbao@caas.cn (D.S.) \\ 2 Key Laboratory of Prevention and Control of Residual Pollution in Agricultural Film, \\ Ministry of Agriculture and Rural Affairs, Beijing 100081, China \\ 3 Institute of Applied Sciences and Intelligent System, Italian National Research Council, 00185 Roman, Italy; \\ massimo.rippa@isasi.cnr.it (M.R.); pasquale.mormile@isasi.cnr.it (P.M.) \\ * Correspondence: yanchangrong@caas.cn (C.Y.); liuqin02@caas.cn (Q.L.)
}

Received: 21 October 2020; Accepted: 17 November 2020; Published: 24 November 2020

\begin{abstract}
The actctivated carbon + solar radiation membrane is an eco-friendly soil disinfestations method for managing soil-borne plant pathogens. However, little was known the impact of Activated carbon + solar radiation membrane on bacterial community structure in strawberry production systems under field conditions. A comprehensive evaluation of the impacts of different soil disinfection methods on the bacterial community structure is fundamental to understand the role of disinfection in maintaining soil health. The changes in the soil bacterial diversity and community composition were detected using realtime fluorescence quantitative PCR (RTFQ PCR) and next-generation sequencing techniques to better understand the effect of soil disinfection. The bacterial community composition was monitored after disinfection using dazomet (DZ), chloropicrin (CP), $100 \mathrm{~kg} / \mathrm{ha}$ activated carbon + solar radiation membrane (AC1), $200 \mathrm{~kg} / \mathrm{ha}$ activated carbon + solar radiation membrane (AC2), and $300 \mathrm{~kg} / \mathrm{ha}$ activated carbon + solar radiation membrane (AC3) and compared with the control (CT). The results indicated that the different dosages of activated carbon (AC1, AC2, and AC3) did not affect the bacterial community structure. On the other hand, DZ and CP considerably reduced the soil biomass and abundance of bacterial species. Chemical fumigants influenced the bacterial community structure, with DZ treatment leading to the dominance of the phylum Firmicutes, accounting for approximately 54\%. After fumigation with CP, Proteobacteria and Acidobacteria were the dominant phyla. Beta diversity analysis and principal coordinate analysis revealed that the bacterial communities in the soil treated with DZ and CP formed clusters. Redundancy analysis indicated that soil $\mathrm{pH}$, available potassium, and available phosphorus were the key factors influencing microbial metabolic functional diversity. Thus, it was verified that the damage caused by activated carbon + solar radiation membrane-a potential alternative for chemical fumigant-to the soil bacterial community was less than that caused by chemicals DZ and CP.
\end{abstract}

Keywords: soil disinfection; solar radiation membrane; chemical fumigants; next-generation sequencing; bacterial community

\section{Introduction}

As a result of the shortage of land resources, the changes in the cultivation habits of farmers to reap economic benefits such as planting the same crop (including continuous cropping and simple rotation) and high input of water and fertilizers has become common phenomena in the cultivation of protected 
crops in China [1,2]. Plantation of the same crop every year can result in changes in soil microflora and predominant microorganisms $[3,4]$. This makes the soil vulnerable and leads to the deterioration of soil physicochemical properties, accumulation of plant autotoxins, reduction in microbial diversity, and increased abundance of pathogenic bacteria, thus leading to continuous cropping obstacles. Although complex factors result in continuous cropping obstacles, they are ultimately owing to the imbalance of the soil ecosystem [5].

The soil microbial community is widely accepted as an integrative component of soil quality owing to the crucial involvement of soil microbes in multiple ecosystem processes [6-9]. At the same time, the soil microbial community plays a crucial role in the recycling of nutrients and maintenance of soil structure. Therefore, microbial diversity is a sensitive indicator of soil quality that can reflect subtle changes in the soil and provide information for the evaluation of soil functions [10]. In a healthy soil ecosystem, the species of beneficial microorganisms are significantly more abundant than those of harmful microorganisms. Continuous cropping can destroy the soil microbial community structure and species diversity, promote the growth and accumulation of pathogenic microorganisms, inhibit the propagation of beneficial microorganisms, and significantly reduce the crop yield [11-13]. Therefore, it is important to study the role of soil microorganisms in preventing continuous cropping obstacles to control soil-borne diseases effectively and to realize the sustainable development of a protected cultivation system.

According to previous studies, soil fumigation is currently the most effective method of controlling soil-borne pests and diseases in high-value crops [14]. Soil fumigation, also known as soil disinfection, uses chemical, physical, and biological methods to kill harmful soil organisms, control insect pests, and prevent the occurrence of soil-borne diseases to ensure sustainable agricultural production [15]. Methyl bromide (MB) has been the most widely used fumigant since 1940 because of its broad-spectrum activity. However, it has been gradually phased out in developed countries because of its detrimental effects on the stratospheric ozone layer [16]. In recent years, some substitutes for $\mathrm{MB}$, such as 1,3-dichloropropene (1,3-D), chloropicrin (CP), metam sodium, dazomet (DZ), and dimethyl disulfide, as well as various substitution technologies, have been continuously developed for controlling soil-borne diseases [17-19]. However, soil chemical fumigation is recognized as a destructive method non-selective to soil biological targets, resulting in different degrees of change in the diversity and abundance of soil microorganisms, as well as soil enzymatic activities. Besides, there are significant differences in the effects of various chemical fumigants on soil microorganisms [20]. A large number of studies have indicated that the combination of $\mathrm{CP}$ and 1,3-D has a significant impact on the prevention and control of soil-borne diseases and insect pests and thus is widely considered a good MB substitute [21-24]. However, in recent years, some reports have indicated that 1,3-D leads to environmental pollution, and the combination of $\mathrm{CP}$ and 1,3-D would be impeded. Moreover, the use of a large volume of chemical pesticides can lead to a series of problems, including environmental damage, soil ecological imbalance, food pollution, and declining public health [25-30]. Therefore, it is crucial to seek efficient and environment-friendly soil-disinfection methods to reduce the number of soil pathogenic bacteria and improve the soil environment such that it is no longer suitable for the growth of pathogenic bacteria.

Activated carbon, as an environment-friendly soil disinfectant, is a charcoal powder obtained by plant carbonization, which has a rich porous structure with complex and diverse features. The porous structure can provide a better environment and habitat for microorganisms that can aid the growth of beneficial microorganisms and inhibit the reproduction of pathogenic bacteria [31]. Activated carbon management can improve the soil physicochemical properties such as the water-holding capacity. Concurrently, it can be used for soil improvement to increase the crop yield without affecting the soil bacterial community structure [32,33]. Pasquale et al. [34] developed a novel solarization method based on activated carbon in addition to the transparent thermal film, simulating a domestic "solar panel" useful to produce hot water. This method can increase the water temperature in the soil, thus resulting in a high soil temperature and better sterilizing effect in a short time. However, there are only a few 
reports on the influence of disinfection using the combination of activated carbon and solar radiation membrane on the soil bacterial community structure. Therefore, considering the strawberry continuous cropping field with severe soil-borne diseases Xingshou town in Changping, Beijing as the research site, the effects of different soil disinfection methods on the soil bacterial community structure and diversity, as well as the relationship between bacterial community and soil environmental factors, were evaluated using 16S rRNA macro genomics on the Illumina MiSeq Sequencing platform. This research can provide a scientific basis for the adoption of appropriate adjustment and control measures to overcome continuous cropping obstacles in protected strawberry cultivation.

\section{Materials and Methods}

\subsection{Study Site}

Trials were arranged in the strawberry crop area of Huaxiang garden located in Xingshou city of Changping. The experimental area has four distinct seasons and is characterized by a temperate continental climate. The mean annual average temperature was $11.8^{\circ} \mathrm{C}$, and the annual average precipitation was $550.3 \mathrm{~mm}$. The experimental greenhouse was $50-\mathrm{m}$ long and 8-m wide. The strawberries were grown in the greenhouse over the past ten years, with the last stubble harvested in May 2019. The soil pH was 7.44, and the soil organic matter (SOM) content was $19.59 \mathrm{~g} / \mathrm{kg}$ with $0.76 \mathrm{~g} / \mathrm{kg}$ of total nitrogen (TN), $25.77 \mathrm{mg} / \mathrm{kg}$ of available phosphorus (AP), and $334.60 \mathrm{mg} / \mathrm{kg}$ of available potassium (AK).

\subsection{Experimental Design}

Tests were performed, adopting a randomized-block method. The disinfection was carried out using DZ, CP, $100 \mathrm{~kg} / \mathrm{ha}$ activated carbon + solar radiation film (AC1), $200 \mathrm{~kg} / \mathrm{ha}$ activated carbon + solar radiation film (AC2), and $300 \mathrm{~kg} / \mathrm{ha}$ activated carbon + solar radiation film (AC3), with three replicates for each treatment. The treated samples were compared with the control (CT). The special injection equipment was used to inject chlorinated bitters liquor into the ground at a depth of $15 \mathrm{~cm}$, and then immediately covered with the film after fumigant application. In the case of AC1, the soil was thoroughly watered the day before application, and the activated carbon was uniformly spread on the soil surface in order to create a sort of "solar collector" able to collect, like a black body, totally the incident radiation. The parcels were covered with transparent plastic films with special optical properties able to block a wide percentage of the radiation emitted from the soil in the medium Infrared (IR) region. After 20 days, the plastic film was removed.

\subsection{Sampling and Analysis}

\subsubsection{Soil Sampling}

A 5-point sampling and mixing method was used. The soil layer (approximately $0-10 \mathrm{~cm}$ ) was collected before and after soil disinfection (after removing the membrane). The collected samples were placed in an icebox and transported to the laboratory. All the freshly collected soil samples were divided into two parts: one stored at $4{ }^{\circ} \mathrm{C}$ for chemical analysis and the other stored at $-80{ }^{\circ} \mathrm{C}$ for DNA extraction.

\subsubsection{Analysis of Soil Chemical Properties}

The soil chemical properties were measured using the methods described by Bao [35]. Soil organic carbon (SOC) was measured with the vitriol acid-potassium dichromate oxidation method, with $0.8 \mathrm{~mol} / \mathrm{L} 1 / 6 \mathrm{~K}_{2} \mathrm{CrO}_{7}$ at $170-180^{\circ} \mathrm{C}$ for $5 \mathrm{~min}$, followed by titration of the digestates with $\mathrm{FeSO}_{4}$; total nitrogen (TN) was measured using the Kjeldahl method; available potassium (AK) in the soil was measured using flame photometry; available phosphorus (AP) was analyzed by the $\mathrm{NaHCO}_{3}$ method. The $\mathrm{pH}$ of the soil was measured with a glass electrode in a 1:5 soil/water suspension. 


\subsubsection{DNA Extraction and PCR Amplification}

The soil DNA was extracted using the PowerSoil DNA Isolation Kit (MoBio Laboratories, Carlsbad, CA, USA), following the manual provided with the kit. The purity and quality of the genomic DNA were checked on $1 \%$ agarose gel and a NanoDrop Spectrophotometer (Thermo Scientific). The V3-V4 hypervariable region of the bacterial 16S rRNA gene was amplified using the primers 338F (ACTCCTACGGGAGGCAGCAG) and 806R (GGACTACHVGGGTWTCTAAT) [36]. For each soil sample, an 8-digit barcode sequence was added to the $5^{\prime}$ end of the forward and reverse primers (Allwegene Company, Beijing). The Polymerase Chain Reaction (PCR) was carried out on a Mastercycler Gradient (Eppendorf, Germany) using $25 \mu \mathrm{L}$ of the reaction volume, containing $12.5 \mu \mathrm{L}$ of KAPA $2 \mathrm{G}$ Robust Hot Start Ready Mix, $1 \mu \mathrm{L}$ of Forward Primer $(5 \mu \mathrm{M}), 1 \mu \mathrm{L}$ of Reverse Primer $(5 \mu \mathrm{M}), 5 \mu \mathrm{L}$ of DNA (total template quantity of $30 \mathrm{ng}$ ), and $5.5 \mu \mathrm{L}$ of $\mathrm{H}_{2} \mathrm{O}$. The cycling parameters were as follows: $95{ }^{\circ} \mathrm{C}$ for $5 \mathrm{~min}$, followed by 28 cycles of $95{ }^{\circ} \mathrm{C}$ for $45 \mathrm{~s}, 55^{\circ} \mathrm{C}$ for $50 \mathrm{~s}$, and $72{ }^{\circ} \mathrm{C}$ for $45 \mathrm{~s}$ with a final extension at $72{ }^{\circ} \mathrm{C}$ for $10 \mathrm{~min}$. The PCR products were purified using the Agencourt AMPure XP Kit.

\subsubsection{Illumina MiSeq Sequencing}

The PCR products were used for constructing a microbial sequence repository, and Illumina MiSeq PE300 high-throughput sequencing platform was used for paired-end sequencing at Beijing allwegene gene technology co., LTD. The original sequence was uploaded to the Sequence Read Archive (SRA) database of National Center of Biotechnology Information (NCBI).

\subsection{Statistical Analysis}

In the barcode sequencing technique, the offline data were separated with QIIME1 (v1.8.0) software. Further, the data were filtered and spliced using PEAR (v0.9.6) software by removing the low score value of 20, containing fuzzy base and primer mismatch sequences [37,38]. For stitching, the minimum overlap was set at $10 \mathrm{bp}$, and the mismatch rate was 0.1. After splicing, VSEARCH (v2.7.1) software deleted the sequences with a length of less than $230 \mathrm{bp}$, and the chimeric sequences were compared and removed by the UCHIME method based on the Gold database. In the end, the VSEARCH software UPARSE algorithm conducted the operational taxonomic unit (OTU) clustering for high-quality sequences, and the observed similarity value was 97\% [39]. RDP classifier algorithm compared the observed sequences with the SILVA128 database. A 70\% confidence coefficient was set to obtain the information on the classification of species corresponding to each OTU [40]. To identify the phylogenetic relationships between different OTUs and different predominant bacterial genera in the samples, MUSCLE software implements a multi-sequence comparison [41]. Based on the minimum number of sequences in the samples, the OTU chart was modified to obtain results showing a relative comparison of average sequences in the samples. Further, the relative abundance of each OTU was calculated based on the diluted OTU chart.

The bacterial species diversity in each sample known as alpha diversity analysis was conducted by calculating five diversity indices: Observed species, Chao1, Shannon, Simpson, and Good's coverage. All these indices were calculated using QIIME1 (v1.8.0) software. Beta diversity analysis was used to assess the differences in the bacterial species in different samples. Further, QIIME1 (v1.8.0) was used to calculate the beta diversity distance matrix [42]. Shifts inbacterial community composition were visualized using PrincipalCoordinate Analysis (PCoA) of pairwise Bray-Curtis dissimilarity matrices based on $97 \%$ OTU similarity across different samples. The PCoA results were displayed using the WGCNA package, stat packages and ggplot2 package in $\mathrm{R}$ (Version 2.15.3). Based on the beta diversity distance matrix [43], a hierarchical clustering analysis can be conducted. The UPGMA (Unweighted pair group method with arithmetic mean) was used to construct the tree-like structure for visual analysis.

The single-factor variance and multiple comparative analysis $(p<0.05)$ to determine statistical differences between the effects of different disinfection methods on soil chemical quality and bacterial 
diversity was performed using SPSS19.0 software. The relationship between the soil environmental factors and predominant bacterial flora was analyzed using CANOCO 4.5 for redundancy analysis (RDA) [44].

\section{Results}

\subsection{Soil Physicochemical Properties}

As can be seen in Table 1, there were no significant changes in $\mathrm{SOM}, \mathrm{TN}$, and $\mathrm{pH}$ after DZ and CP treatment $(p>0.05)$ when compared with CT. AP decreased by $38.39 \%$ and $26.47 \%$ after DZ and CP treatment, respectively. There was no change in AK after DZ treatment; however, AK significantly reduced by $10.88 \%$ after $\mathrm{CP}$ treatment. When the treatment was carried out using different dosages of activated carbon-AC1, AC2, and AC3 - no significant changes were observed in $\mathrm{TN}, \mathrm{AK}$, and $\mathrm{AP}$ in soil $(p>0.05)$. Although, there was an increase in the activated carbon content, no significant changes in SOM were observed after AC1 and AC2 treatment. On the other hand, the OM increased significantly by $11.02 \%$ after AC 3 treatment.

Table 1. Effects of different soil disinfection methods on soil nutrients.

\begin{tabular}{cccccc}
\hline Treatment & $\begin{array}{c}\text { Soil Organic } \\
\text { Matter (g/kg) }\end{array}$ & $\begin{array}{c}\text { Total Nitrogen } \\
\mathbf{( g / \mathbf { k g } )}\end{array}$ & $\begin{array}{c}\text { Available } \\
\text { Potassium } \\
\mathbf{( m g} / \mathbf{k g})\end{array}$ & $\begin{array}{c}\text { Available } \\
\text { Phosphorus } \\
\mathbf{( m g} / \mathbf{k g})\end{array}$ & $\mathbf{p H}$ \\
\hline $\mathrm{CT}$ & $21.77 \pm 1.03 \mathrm{~b}$ & $0.95 \pm 0.02 \mathrm{a}$ & $294 \pm 8.02 \mathrm{ab}$ & $25.79 \pm 1.57 \mathrm{ab}$ & $7.80 \pm 0.13 \mathrm{ab}$ \\
$\mathrm{DZ}$ & $20.34 \pm 1.24 \mathrm{~b}$ & $1.08 \pm 0.15 \mathrm{a}$ & $292 \pm 11.68 \mathrm{ab}$ & $15.89 \pm 1.93 \mathrm{c}$ & $7.88 \pm 0.09 \mathrm{a}$ \\
$\mathrm{CP}$ & $20.71 \pm 0.63 \mathrm{~b}$ & $1.01 \pm 0.10 \mathrm{a}$ & $262 \pm 9.07 \mathrm{~b}$ & $19.04 \pm 2.71 \mathrm{c}$ & $7.62 \pm 0.10 \mathrm{~b}$ \\
$\mathrm{AC} 1$ & $20.40 \pm 1.83 \mathrm{~b}$ & $1.03 \pm 0.03 \mathrm{a}$ & $281 \pm 23.76 \mathrm{ab}$ & $23.34 \pm 2.62 \mathrm{~b}$ & $7.84 \pm 0.17 \mathrm{a}$ \\
$\mathrm{AC} 2$ & $20.83 \pm 1.67 \mathrm{~b}$ & $1.06 \pm 0.03 \mathrm{a}$ & $285 \pm 23.67 \mathrm{ab}$ & $23.34 \pm 1.32 \mathrm{~b}$ & $7.83 \pm 0.06 \mathrm{a}$ \\
$\mathrm{AC} 3$ & $24.17 \pm 1.07 \mathrm{a}$ & $1.07 \pm 0.08 \mathrm{a}$ & $322 \pm 11.14 \mathrm{ab}$ & $28.07 \pm 1.57 \mathrm{a}$ & $7.89 \pm 0.06 \mathrm{a}$ \\
\hline
\end{tabular}

Data represented as mean \pm standard deviation. Different letters in the same column indicate significant differences $(p<0.05)$.

\subsection{Soil Bacterial Abundance and Diversity Indices}

A total of 1099708 effective reads and 42591 OTUs were obtained from 16S rRNA amplification sequencing following quality trimming. As shown in Table 2, the sequencing coverage of all the samples was above $97 \%$, indicating the measurement of most of the sample sequences. When compared with $\mathrm{CT}$, the number of microbial species declined after different disinfection methods, with the highest decline observed after $\mathrm{CP}$ treatment $(p<0.05)$. Both Shannon and Simpson indices followed the order $\mathrm{AC} 2>\mathrm{CT}>\mathrm{AC} 1>\mathrm{AC} 3>\mathrm{DZ}>\mathrm{CP}$, indicating that the indices were lowest in $\mathrm{CP}$ treatment followed by DZ treatment. Further, the indices in $\mathrm{AC} 1, \mathrm{AC} 2$, and $\mathrm{AC} 3$ treatment were not significantly different from those in CT $(p>0.05)$. According to the bacterial richness index Chao1, significant differences were observed between $\mathrm{CT}$ and $\mathrm{CP}$ treatment, but no significant differences were observed between $\mathrm{CT}$ and other treatments. This indicated that the treatment with chemical fumigants DZ and CP led to a significant decrease in the soil bacterial abundance and diversity, whereas treatment with AC1, AC2, and AC3 had minimal influence.

\subsection{Effects of Different Disinfection Methods on the Bacterial Community Composition and Predominant Bacterial Species}

\subsubsection{Distribution Characteristics of Predominant Soil Bacterial Phyla}

UPGMA clustering dendrogram (Figure 1) was used to assess the differences between the bacterial compositions of the samples after different disinfection methods. The CT samples and samples subjected to $\mathrm{AC} 1, \mathrm{AC} 2$, and $\mathrm{AC} 3$ treatment were grouped. Both $\mathrm{DZ}$ and $\mathrm{CP}$ treated samples were observed to be distinct from other samples. The phyla Firmicutes, Proteobacteria, Actinobacteria, Acidobacteria, 
Gemmatimonadetes, and Chloroflexi were predominant across all the samples. The results revealed that different soil disinfection methods did not cause significant changes in the soil bacterial species but significantly altered the proportion of predominant bacterial flora. After fumigation with DZ, Firmicutes and Proteobacteria accounted for the highest proportions with $54.41 \%$ and $12.91 \%$, respectively. Compared with that in CT, the relative abundance of Firmicutes significantly increased in the DZ treated sample, whereas the relative abundance of Proteobacteria and Acidobacteria reduced. After fumigation with CP, Firmicutes were the predominant phylum accounting for approximately $30.25 \%$ of the total bacteria flora. Compared with that in CT, the relative abundance of Actinobacteria in CP fumigated samples significantly increased, but the relative abundance of Proteobacteria and Gemmatimonadetes significantly reduced. However, the relative abundance of bacterial population was not affected by $\mathrm{AC} 1, \mathrm{AC} 2$, and $\mathrm{AC} 3$. These results indicated that the original soil bacterial community structure was damaged after fumigation with DZ and CP. On the other hand, AC1, AC2, and AC3 did not lead to any significant changes in the composition and relative abundance of the original microbial community structure.

Table 2. Effects of different disinfection methods on the diversity indices of soil bacterial community.

\begin{tabular}{cccccc}
\hline Treatment & $\begin{array}{c}\text { Observed } \\
\text { Species }\end{array}$ & $\begin{array}{c}\text { Good's } \\
\text { Coverage }\end{array}$ & $\begin{array}{c}\text { Shannon } \\
\text { Index }\end{array}$ & Simpson Index & Chao1 Index \\
\hline CT & $2457(55)$ & $97.12(0.09)$ & $8.64(0.07)$ & $0.989(0.001)$ & $3488.73(114.23)$ \\
DZ & $2359(54)$ & $97.26(0.10)$ & $8.27(0.08)^{*}$ & $0.984(0.002)^{*}$ & $3356.27(132.39)$ \\
CP & $2308(32)^{*}$ & $97.36(0.05)^{*}$ & $7.99(0.11)^{* *}$ & $0.981(0.001)^{* *}$ & $3211.44(72.37)^{*}$ \\
AC1 & $2348(41)$ & $97.22(0.06)$ & $8.54(0.06)$ & $0.988(0.001)$ & $3351.14(56.35)$ \\
AC2 & $2422(87)$ & $97.23(0.04)$ & $8.68(0.19)$ & $0.990(0.002)$ & $3389.39(43.34)$ \\
AC3 & $2322(127)$ & $97.17(0.05)$ & $8.44(0.29)$ & $0.987(0.003)$ & $3436.68(99.97)$ \\
\hline
\end{tabular}

Data represented as mean (standard error) of three independent biological replicates. Compared with the control group, the statistical significance is showed by $\left.{ }^{*} p<0.05,{ }^{* *} p<0.01\right)$.
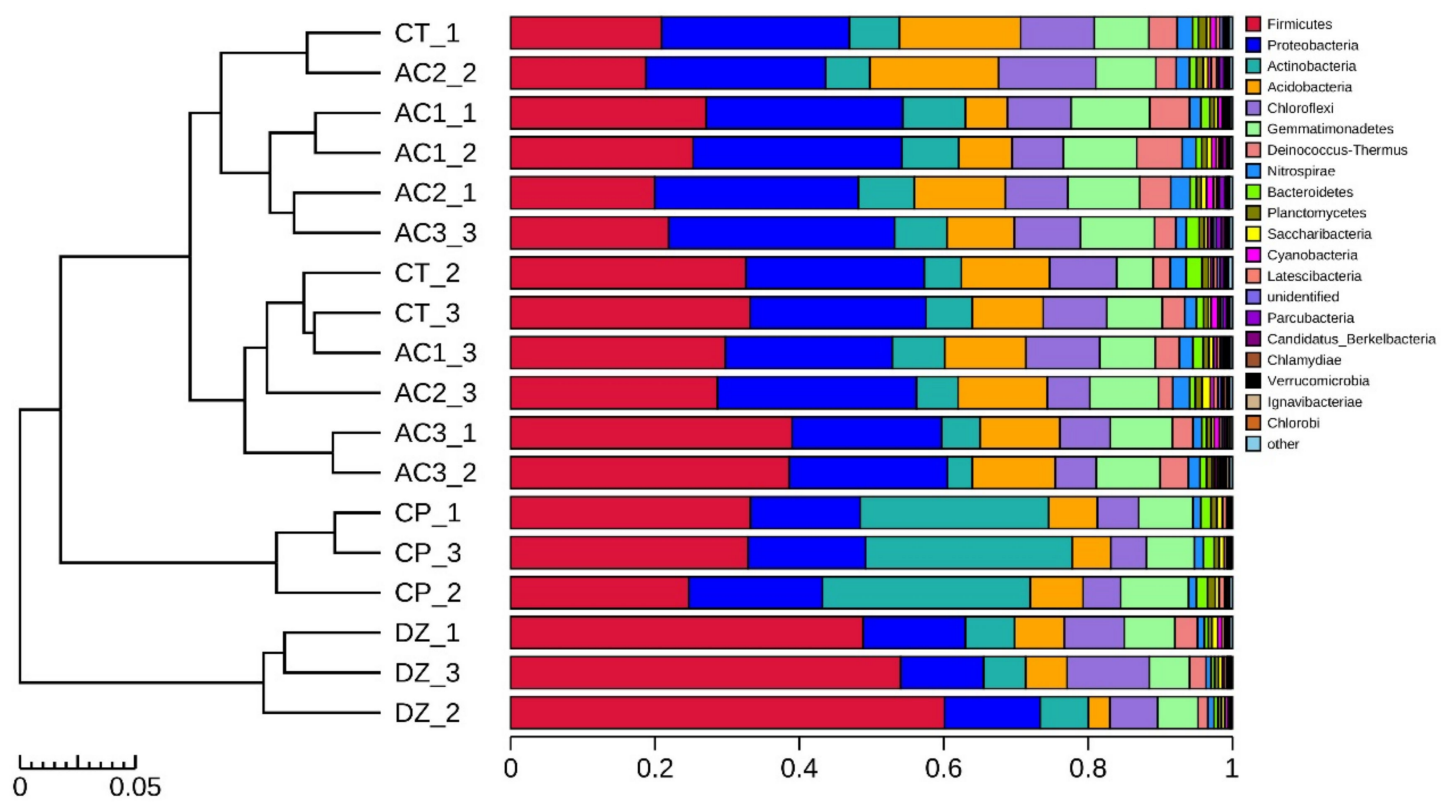

Figure 1. Composition and relative abundance of bacterial phyla after the use of different disinfection methods.

\subsubsection{Distribution Characteristics of Predominant Soil Bacterial Llasses}

The analysis of samples subjected to different soil disinfection methods determined that twenty bacterial classes were present (Figure 2). Among these, Clostridia, Bacillus, Alphaproteobacteria, 
Gammaproteobacteria, and Subgroup-6 were the major bacterial classes. Compared with that in CT, the relative abundance of Clostridia and Bacillus was pronouncedly found to increase (i.e., by $96.2 \%$ and $95.9 \%$, respectively) after DZ fumigation, whereas the relative abundance of Alphaproteobacteria, Gammaproteobacteria, and Subgroup-6 drastically reduced (i.e., by $30.7 \%, 66.5 \%$, and $61.1 \%$, respectively). Compared with that in CT, the relative abundance of Clostridia, Alphaproteobacteria, Gammaproteobacteria, and Subgroup- 6 largely declined (i.e., by $87 \%, 17.8 \%, 45.2 \%$, and $48.1 \%$, respectively) after $\mathrm{CP}$ fumigation. On the contrary, the relative abundance of Bacillus increased by $232.6 \%$. There were no significant differences in the bacterial community structure at the class level under the influence of AC1, AC2, and AC3.

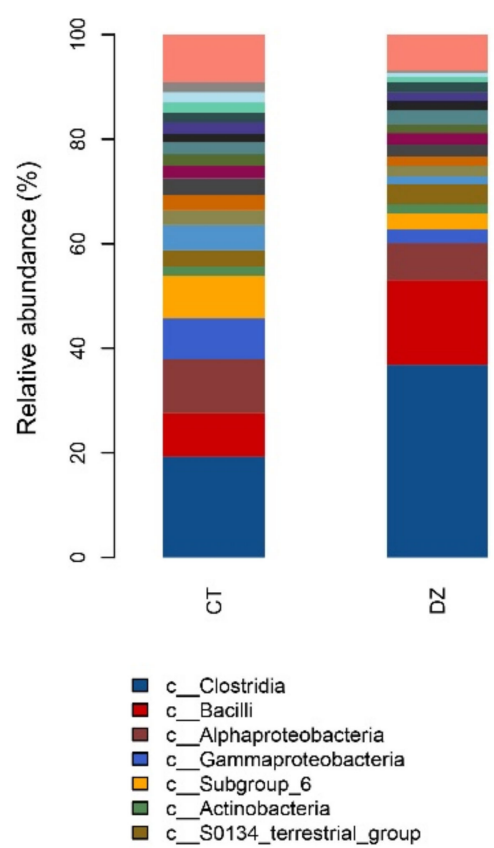

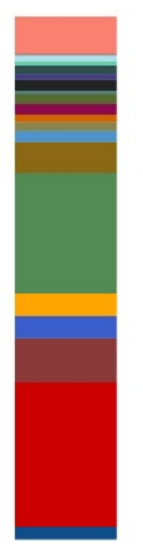

$\stackrel{0}{0}$

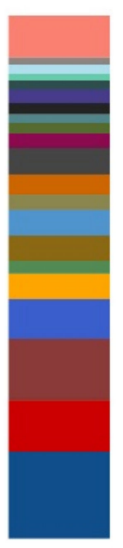

$\bar{ষ}$

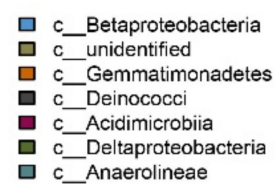

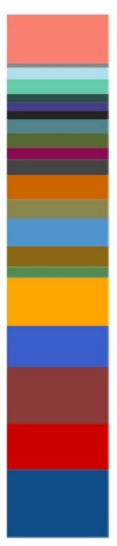

ชัญ

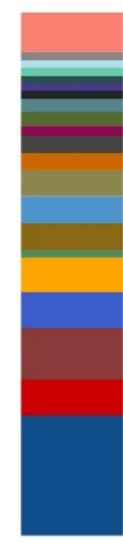

ஜृ

Figure 2. Composition and relative abundance of bacterial classes after different disinfection methods.

\subsubsection{Distribution Characteristics of Predominant Soil Bacterial Genera}

As described in Figure 3, 20 genera were identified from the heat maps and clustering analysis of the samples subjected to different disinfection methods. When compared with that in $\mathrm{CT}$, the relative abundance of Schlegelella, Bryobaacter, Vulcaniibacterium, and Steroidobacter significantly decreased after DZ fumigation, whereas the relative abundance of Caldinitratiruptor and Symbiobacterium significantly increased, and some new predominant bacterial genera, such as Thermicanus, were identified. Moreover, the relative abundance of Bryobacter, Steroidobacter, and Symbiobacterium significantly reduced whereas that of Acidibacter and Bacillus significantly increased. Schlegelella, Vulcaniibacterium, and Caldinitratiruptor completely disappeared after fumigation with CP. There was no change in the soil bacterial community and composition on the addition of activated carbon, but the relative abundance of Steroidobacter and Symbiobacterium significantly increased. Thus, significant differences were detected in the bacterial community structure at the genus level in the DZ and CP treated samples. Contrarily, no significant changes were found in the soil bacterial community of the samples subjected to $\mathrm{AC} 1$, $\mathrm{AC} 2$, and AC3.

\subsection{Beta Diversity Analysis}

The major effects of different soil-disinfection methods on the soil bacterial community structure can be determined using OUT hierarchical clustering analysis, as described in Figure 4. There was a shorter distance between $\mathrm{AC} 1, \mathrm{AC} 2$, and $\mathrm{AC} 3$ and $\mathrm{CT}$, indicating that there were not many differences 
between CT and activated carbon treated samples. DZ and CP were located away from CT, implying significant differences between $\mathrm{CT}$ and chemical fumigated samples.

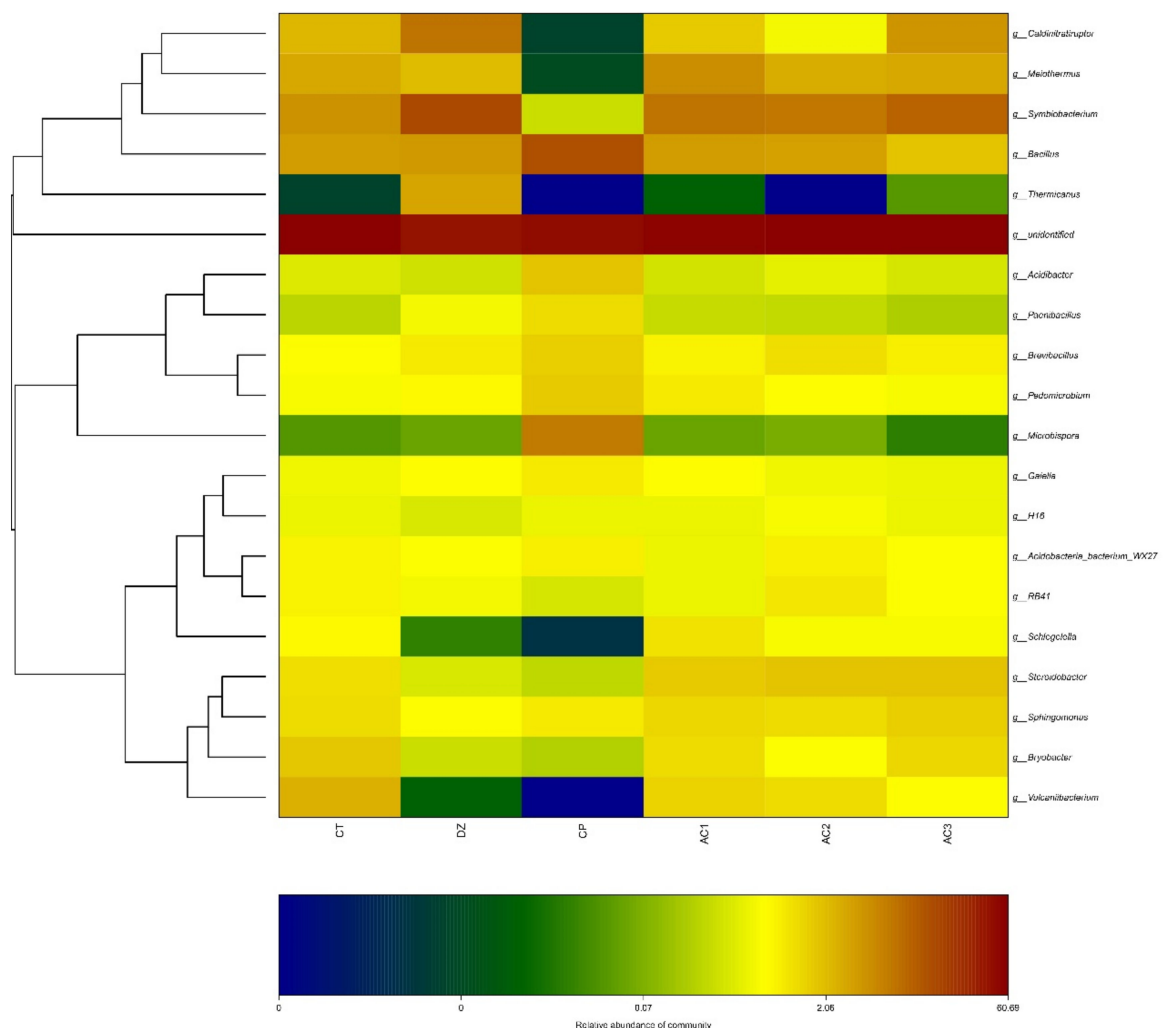

Figure 3. Representation of the differences in soil bacterial genera after the use of different disinfection methods by clustering and heat maps.

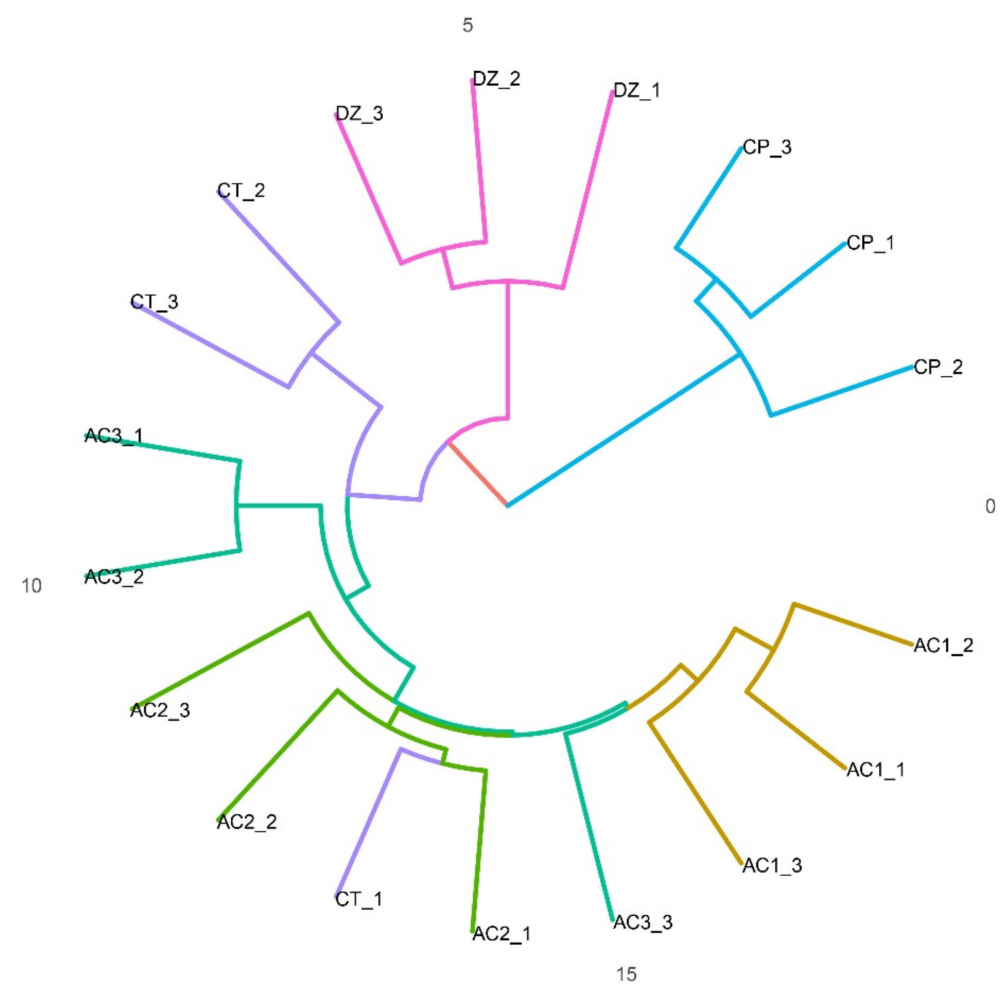

Figure 4. Multi-sample clustering tree based on Bray-Curtis distance. 
UniFrac-weighted PCoA based on the OTU composition also clearly demonstrated variations between the different soil samples, with the first two axes explaining $41.49 \%$ and $22.62 \%$ of the total variation in the bacterial composition (Figure 5). Thus, the two components, PC1 and PC2, together accounted for $64.11 \%$ of the total variance in all the variables. The data from CT samples and samples subjected to $\mathrm{AC} 1, \mathrm{AC} 2$, and $\mathrm{AC} 3$ were distributed in the same quadrant (third quadrant), implying that there were not many differences in the soil bacterial community composition between $\mathrm{CT}$ and activated carbon-treated samples. The data from DZ- and CP-treated samples were distributed in the first and second quadrants, respectively, implying that the bacterial community composition significantly changed after chemical fumigation.

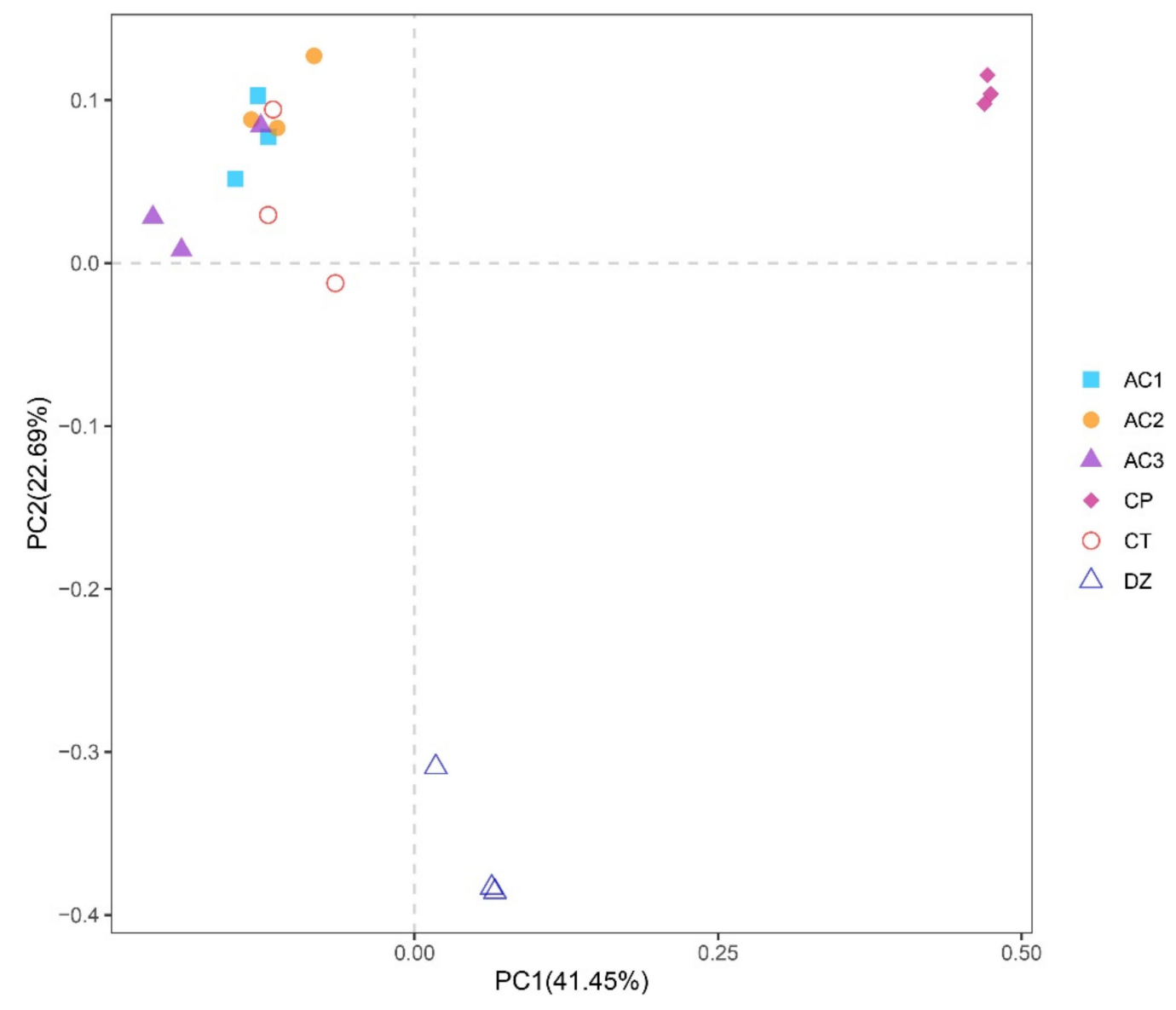

Figure 5. PCoA based on Bray-Curtis distance.

\subsection{Effects of Different Disinfection Methods on Soil Properties and Predominant Bacterial Communities}

The correlations between the soil bacterial community structure and other soil properties were evaluated using ordination plots of RDA. Five major environmental factors- $\mathrm{pH}, \mathrm{SOC}, \mathrm{TN}, \mathrm{AK}$, and $\mathrm{AP}$ - and the first five bacteria phyla-Firmicutes, Proteobacteria, Actinomycetes, Acidobacteria, and Gemmatimonadetes - were included in the RDA (Figure 6). According to the RDA, DZ-treated samples were significantly separated from CT samples, and there was no significant separation between activated carbon treated samples and CT samples. It can be stated that the explanatory variables account for $65.7 \%$ of the total variance in the model, whereas the first and second axes account for $43.59 \%$ and $21.54 \%$ of the total variance, respectively. According to the Monte Carlo permutation test results, soil pH, AP, and AK accounted for 31.2\% $(p<0.01), 25.9 \%(p<0.01)$, and $7.3 \%(p<0.05)$ of the total variation in the predominant soil bacterial flora, indicating that these factors considerably affected the predominant bacterial community structure. 


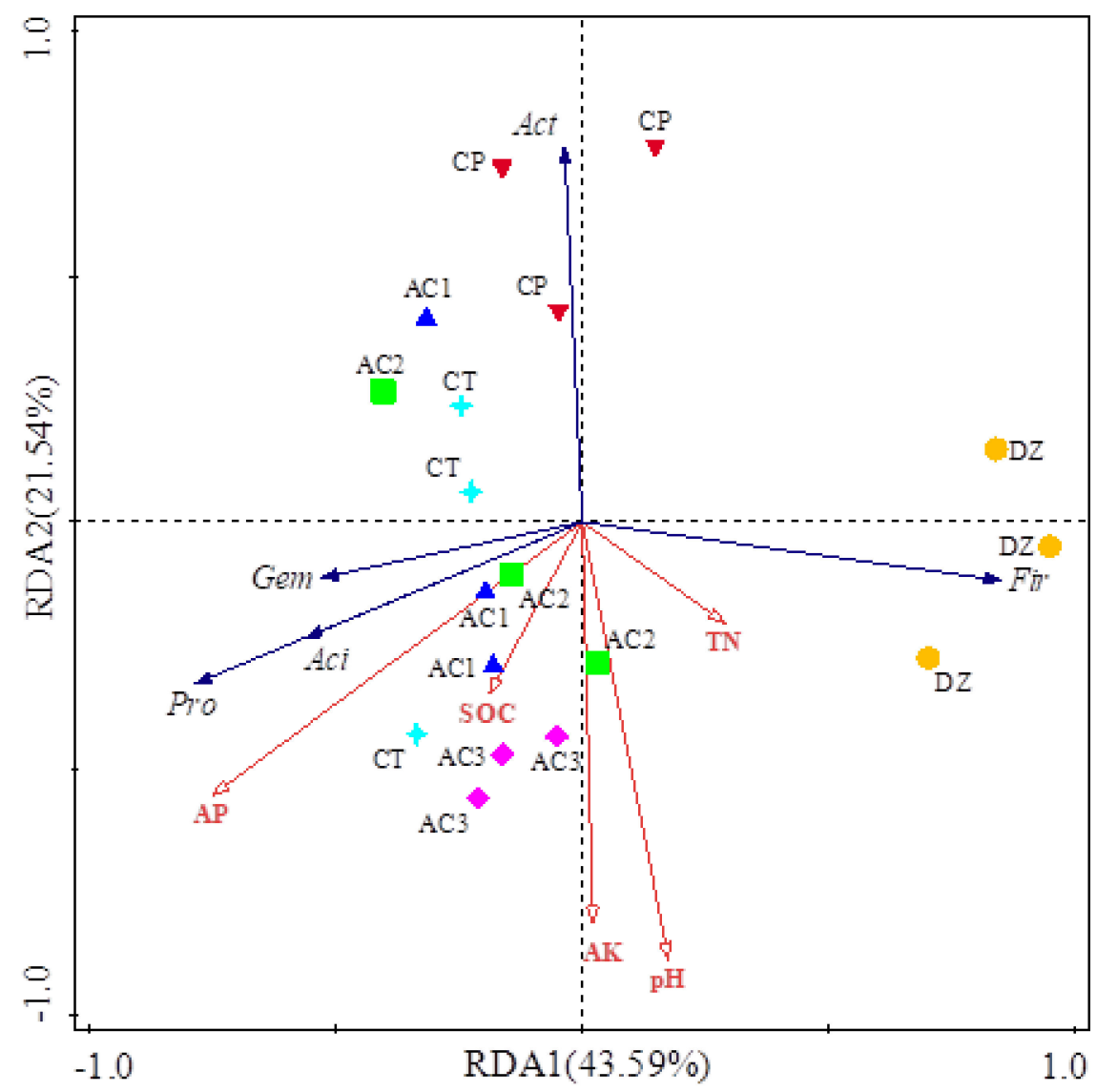

Figure 6. Redundancy analysis to determine the effect of soil properties on the bacterial community structure. (SOC: soil organic carbon; TN: total nitrogen; AK: available potassium; AP: available phosphorus; Fir: Firmicutes; Pro: Proteobacteria; Act: Actinomycetes; Aci: Acidobacteria; Gem: Gemmatimonadetes).

\section{Discussion}

\subsection{Effects of Different Disinfection Methods on Bacterial Diversity}

Soil microorganisms play an important role in maintaining soil stability and restoring the damaged soil system, thus closely determining the health of the soil system. The ability of the soil microorganisms to recover after the treatment of the agricultural area with pesticides is critical for the development of healthy soils. The ideal pesticide is the one that is toxic only to the target organisms. However, fumigants are a class of pesticides with broad activity and affect many non-target soil organisms [45]. As a highly toxic pesticide, $\mathrm{CP}$ produces strong acidic substances after entering the biological tissues, leading the cells to swell and rot. It can also dehydrate the cells and precipitate intracellular proteins, thereby causing cell poisoning and death. It can kill soil fungi and bacteria, nematodes, pests, etc., and reduce the abundance and diversity of soil bacteria, as observed in previous studies [46-49]. DZ is a broad-spectrum fumigant. Methyl isothiocyanate (MITC), as an active ingredient in DZ, kills most bacteria, fungi, and other microorganisms [50,51]. DZ belongs to the category of destructive soil fungicides that can kill most of the soil microbes and reduce the soil indigenous microbial population, thus leading to a decrease in the microbial diversity and enrichment index. No significant changes were observed in the soil bacterial abundance and diversity after treatment with activated carbon. This was in agreement with the results reported by Li et al. [52]. However, there are certain differences between the present observations and the results of that study because of the difference in application dosage and particle size of activated carbon and the variation in soil physicochemical properties. 


\subsection{Effects of Different Disinfection Methods on Bacterial Composition}

Our study revealed that there was no change in the soil bacterial species after the use of different soil—disinfection methods. However, disinfection significantly changed the proportion of predominant bacterial species. In particular, the soil bacterial community structure significantly changed after DZ and $\mathrm{CP}$ fumigation. In many studies, DZ fumigation significantly altered the bacterial abundance as well as the abundance, diversity, and composition of the overall microbial community $[53,54]$. The results showed that Firmicutes were the predominant phylum, accounting for $47.4 \%$ of the total bacterial flora. In another study conducted by Rokunuzzaman et al. [46], the phylum Firmicutes were the predominant bacterial phylum (accounting for approximately $75 \%$ of the total). The relative abundance of Proteobacteria and Acidobacteria decreased after treatment with DZ. After CP fumigation, there were no significant changes in the predominant bacterial phyla, which was consistent with the high-throughput sequencing test results observed after soil treatment using 1,3-D [48]. However, contrary to the results reported by Li et al. [49], our study showed that the phylum Proteobacteria was predominant (accounting for approximately $75 \%$ of the total) after fumigation with $\mathrm{CP}$. The probable reason for this inconsistency in the result was the difference in the $\mathrm{CP}$ application dosage between the studies [47], as well as the difference in the soil physicochemical properties, which has been shown to significantly influence the efficacy of the fumigant in the previous study [49]. CP fumigation can significantly influence the abundance of bacterial species in the bacterial community. Moreover, the bacterial classes Clostridia, Alphaproteobacteria, Gammaproteobacteria and Subgroup-6 were significantly reduced, and the relative abundance of original predominant genus reduced or even disappeared. For example, genera Bryobacter, Steroidobacter, and Symbiobacterium were significantly reduced after CP fumigation. Moreover, Schlegelella, Vulcaniibacterium, and Caldinitratiruptor completely disappeared after $\mathrm{CP}$ fumigation, implying that these genera were more sensitive to $\mathrm{CP}$. Briefly, it can be stated that both $\mathrm{DZ}$ and $\mathrm{CP}$ fumigation severely damaged the predominant soil bacterial community structure.

There was no change in the soil bacterial community structure treated with different dosages of activated carbon. Activated carbon has a strong adsorption capacity [55-57] and can adsorb ammonium, nitrate, phosphorus, and other water-soluble salt ions, thus exhibiting a fertilizer-retention property [58]. It can also adsorb pesticides and heavy metals, thus reducing soil and environmental pollution [59]. At the same time, activated carbon consisting of carbon, hydrogen, oxygen, nitrogen, and other nutrient elements provides effective nutrients for plant growth and development and considerably increases soil nitrogen and phosphorus contents [60]. As an excellent soil improver, activated carbon can not only promote the growth of plant seedlings but also help in controlling soil-borne diseases and insect pests [61]. Similar results were reported by Sun, et al. [62], indicating that the addition of activated carbon increased the soil enzymatic activity and reduced the influences of auto-toxic substances on soil enzymes and microorganisms, thereby alleviating the continuous cropping obstacle of processing tomato. A comparative study was conducted to evaluate the effects of $\mathrm{AC} 1, \mathrm{AC} 2$, and $\mathrm{AC} 3$ on the bacterial community. The results revealed that different dosages of activated carbon did not significantly affect the structure and composition of the original soil bacterial community, which was also consistent with the previous results [32,33].

\subsection{Correlation between Soil Characteristics and Predominant Soil Bacterial Flora}

A certain correlation was observed between soil microbial community structure and environmental factors [63]. Subsequently, $\mathrm{pH}$, organic matter, and soil nutrients were considered important factors affecting the soil bacterial community structure $[64,65]$. The change in the soil bacterial community structure affects the stability and health of the ecosystem. In our study, the RDA analysis demonstrated a clear distinction between soil samples subjected to different disinfection methods based on the soil parameters (Figure 6). The RDA analysis and Monte Carlo test revealed that there was a certain correlation between the dominant bacterial community structure and soil environmental factors $(p<0.05)$ after the use of different disinfection methods. Among the factors, soil AP, AK, and $\mathrm{pH}$ had a most significant impacts on the bacterial community, which was in agreement with the previous 
studies [66-68]. The first and second axes explained $43.59 \%$ and $21.54 \%$ of the total variation in the samples, respectively, indicating that the dominant soil bacterial community structure was not only influenced by the environmental factors but also by other factors such as rotation, plant species, temperature, water, and soil type [69-72]. In short, it can be stated that there were varying influences of different disinfection methods and environmental factors on the soil bacterial community structure.

\section{Conclusions}

1. The fumigation using both $\mathrm{DZ}$ and $\mathrm{CP}$ significantly altered the bacterial community structure and significantly reduced the bacterial abundance and diversity. Although there was no change in the composition of the bacterial community at the phylum level, few predominant bacterial genera significantly decreased or disappeared, and a few new predominant bacterial genera emerged after fumigation with DZ and CP. However, no significant change was observed in the abundance and diversity of soil bacterial communities after treatment with AC1, AC2, and AC3.

2. Beta diversity analysis revealed that no significant differences were observed in the soil bacterial community composition after treatment with AC1, AC2, and AC3. However, significant changes were observed in the soil bacterial community composition after treatment with $\mathrm{DZ}$ and $\mathrm{CP}$.

3. RDA revealed that soil $\mathrm{pH}, \mathrm{AK}$, and $\mathrm{AP}$ were the major factors affecting the soil bacterial community structure.

4. Our experimental results indicate that the new solarization system has big potentialities in soil disinfections. We believe that it is possible a further improvement of the system, here presented, increasing the quantity of black powder in order to obtain a more homogeneous black film on the soil, and using a cover plastic film with special optical proprieties able to trap highly the heat energy in the soil. This study is in progress. The goal is to demonstrate that the increased efficiency of the new solarization will be able to eliminate totally pathogens in the soil, like fumigation, thanks to the extraordinary increasing of temperatures (around $70^{\circ} \mathrm{C}$ ). The environment respect, the safeguard of human health and a better quality of crops, using innovative and natural methodological approach for soil treatment, represent the real challenge of the future agriculture.

Author Contributions: C.Y. (Changrong Yan), Q.L., E.L., P.M. and M.R. mostly contributed equally at designing of experiment. C.Y. (Cuixia Yun) and D.S. carried out data collection and processing. C.Y. (Cuixia Yun), Q.L. and P.M. compiled and edited the full text this paper. All authors have read and agreed to the published version of the manuscript.

Funding: This research was supported by the National Key Research and Development Program of China, under grant No. 2019YFA0607403, the Zero-Waste Agricultural Mulch Films for Crops in China project (Newton Fund: Newton UK-China Agritech Challenge 2017; No. 2017YFE0121900), Talent Project of Imported Technology in European Functional Agricultural Film (2021-2022), Central Public-Interest Scientific Institution Basal Research Fund (Y2019LM02-02; BSRF201909).

Acknowledgments: We gratefully acknowledge Jialei Liu, from Institute of Environment and Sustainable Development in Agriculture of CAAS for his English editing and the anonymous reviewers for their valuable comments on the manuscript.

Conflicts of Interest: The authors declare no conflict of interest.

\section{References}

1. Yao, H.; Jiao, X.; Wu, F. Effects of continuous cucumber cropping and alternative rotations under protected cultivation on soil microbial community diversity. Plant Soil 2006, 284, 195-203. [CrossRef]

2. Guo, J.H.; Liu, X.; Zhang, Y.; Shen, J.; Han, W.; Zhang, W.F.; Christie, P.; Goulding, K.W.T.; Vitousek, P.M.; Zhang, F. Significant Acidification in Major Chinese Croplands. Science 2010, 327, 1008-1010. [CrossRef] [PubMed]

3. Laurent, A.S.; Merwin, I.A.; Fazio, G.; Thies, J.E.; Brown, M.G. Rootstock genotype succession influences apple replant disease and root-zone microbial community composition in an orchard soil. Plant Soil 2010, 337, 259-272. [CrossRef] 
4. Aranda, S.; Montes-Borrego, M.; Jiménez-Díaz, R.M.; Landa, B.B. Microbial communities associated with the root system of wild olives (Olea europaea L. subsp. europaea var. sylvestris) are good reservoirs of bacteria with antagonistic potential against Verticillium dahliae. Plant Soil 2011, 343, 329-345. [CrossRef]

5. Gil, S.V.; Meriles, J.M.; Conforto, C.; Figoni, G.; Basanta, M.; Lovera, E.; March, G.J. Field assessment of soil biological and chemical quality in response to crop management practices. World J. Microbiol. Biotechnol. 2009, 25, 439-448.

6. Kennedy, A.C.; Smith, K.L. Soil microbial diversity and the sustainability of agricultural soils. Plant Soil 1995, 170, 75-86. [CrossRef]

7. Degens, B.P.; Schipper, L.A.; Sparling, G.P.; Vojvodic-Vukovic, M. Decreases in organic C reserves in soils can reduce the catabolic diversity of soil microbial communities. Soil Biol. Biochem. 2000, 32, 189-196. [CrossRef]

8. Schutter, M.E.; Sandeno, J.M.; Dick, R. Seasonal, soil type, and alternative management influences on microbial communities of vegetable cropping systems. Biol. Fertil. Soils 2001, 34, 397-410.

9. Yao, H.; He, Z.; Wilson, M.T.; Campbell, C.D. Microbial Biomass and Community Structure in a Sequence of Soils with Increasing Fertility and Changing Land Use. Microb. Ecol. 2000, 40, 223-237. [CrossRef]

10. Larkin, R.P. Characterization of soil microbial communities under different potato cropping systems by microbial population dynamics, substrate utilization, and fatty acid profiles. Soil Biol. Biochem. 2003, 35, 1451-1466. [CrossRef]

11. Lee, M.W.; Shin, H.S.; Choi, H.J. Spore Germination of Some Fungi under Different Soil Conditions in Relation to Fungistasis. Plant Pathol. J. 1985, 13, 195-202.

12. Klein, E.; Katan, J.; Gamliel, A. Soil Suppressiveness to Fusarium Disease Following Organic Amendments and Solarization. Plant Dis. 2011, 95, 1116-1123. [CrossRef] [PubMed]

13. Dong, L.; Xu, J.; Feng, G.; Li, X.; Chen, S. Soil bacterial and fungal community dynamics in relation to Panax notoginseng death rate in a continuous cropping system. Sci. Rep. 2016, 6, 31802. [CrossRef] [PubMed]

14. Fang, W.; Wang, X.; Huang, B.; Zhang, D.; Liu, J.; Zhu, J.; Yan, D.; Wang, Q.; Cao, A.; Han, Q. Comparative analysis of the effects of five soil fumigants on the abundance of denitrifying microbes and changes in bacterial community composition. Ecotoxicol. Environ. Saf. 2020, 187, 109850. [CrossRef]

15. Wang, Q.; Yan, D.; Wang, X.; Lü, P.; Li, X.; Cao, A. Research advances in soil fumigants. J. Plant Prot. 2017, 44, 529-543.

16. Bell, C.H. Fumigation in the 21st century. Crop. Prot. 2000, 19, 563-569. [CrossRef]

17. Xiong, W.; Zhao, Q.; Zhao, J.; Xun, W.; Li, R.; Zhang, R.; Wu, H.; Shen, Q. Different continuous cropping spans significantly affect microbial community membership and structure in a vanilla-grown soil as revealed by deep pyrosequencing. Microb. Ecol. 2015, 70, 209-218. [CrossRef]

18. Benyephet, Y.; Melerovera, J.; Devay, J. Interaction of soil solarization and metham-sodium in the destruction of Verticillium dahliae and Fusarium oxysporum f. sp. vasinfectum. Crop. Prot. 1988, 7, 327-331. [CrossRef]

19. Gilreath, J.P.; Motis, T.N.; Santos, B.M.; Mirusso, J.M.; Gilreath, P.R.; Noling, J.W.; Jones, J.P. Influence of supplementary in-bed chloropicrin application on soilborne pest control in tomato (Lycopersicon esculentum). Crop. Prot. 2005, 24, 779-784. [CrossRef]

20. Hutchinson, C.M.; Mcgiffen, M.E.; Ohr, H.D.; Sims, J.J.; Becker, J.O. Efficacy of methyl iodide and synergy with chloropicrin for control of fungi. Pest Manag. Sci. 2000, 56, 413-418. [CrossRef]

21. Minuto, A.; Gullino, M.L.; Lamberti, F.; Daddabbo, T.; Tescari, E.; Ajwa, H.A.; Garibaldi, A. Application of an emulsifiable mixture of 1,3-dichloropropene and chloropicrin against root knot nematodes and soilborne fungi for greenhouse tomatoes in Italy. Crop. Prot. 2006, 25, 1244-1252. [CrossRef]

22. UNEP. Report of the Methyl Bromide Technical Options Committee. Protecting the Ozone Layer: The United Nations History; United Nations Environmental Programme: Nairobi, Kenya, 2002; pp. 43-60. Available online: https: //wedocs.unep.org/bitstream/handle/20.500.11822/7737/46.pdf?sequence=2\&amp\%3BisAllowed (accessed on 10 September 2020).

23. UNEP. Report of the Methyl Bromide Technical Options Committee; United Nations Environmental Programme: Nairobi, Kenya, 1998; pp. 35-43. Available online: https:/ozone.unep.org/sites/default/files/2019-05/ MBTOC98.pdf (accessed on 10 September 2020).

24. UNEP. Report of the 19th Meeting of the Parties to the Montreal Protocol on Substances that Deplete the Ozone Layer; United Nations Environmental Programme: Nairobi, Kenya, 2007; Available online: https://treaties. un.org/Pages/ViewDetails.aspx?src=IND\&mtdsg_no=XXVII-2-a\&chapter=27\&clang=_en (accessed on 10 September 2020). 
25. Carter, W.P.L.; Luo, D.; Malkina, I.L. Investigation of the atmospheric reactions of chloropicrin. Atmos. Environ. 1997, 31, 1425-1439. [CrossRef]

26. Chen, C.; Green, R.E.; Thomas, D.M.; Knuteson, J.A. Modeling 1,3-dichloropropene fumigant volatilization with vapor-phase advection in the soil profile. Environ. Sci. Technol. 1996, 29, 1816-1821. [CrossRef] [PubMed]

27. Thomas, J.E.; Allen, L.H.; Mccormack, L.A.; Vu, J.C.V.; Dickson, D.W.; Ou, L. Atmospheric Volatilization and Distribution of (Z)- and (E)-1,3-Dichloropropene in Field Beds with and without Plastic Covers. J. Environ. Sci. Health Part B Pestic. Food Contam. Agric. Wastes 2004, 39, 709-723. [CrossRef]

28. Papiernik, S.K.; Dungan, R.S.; Zheng, W.; Guo, M.; Lesch, S.M.; Yates, S.R. Effect of Application Variables on Emissions and Distribution of Fumigants Applied via Subsurface Drip Irrigation. Environ. Sci. Technol. 2004, 38, 5489-5496. [CrossRef]

29. Cryer, S.A.; Wesenbeeck, I.J.V.; Knuteson, J.A. Predicting regional emissions and near-field air concentrations of soil fumigants using modest numerical algorithms: A case study using 1,3-dichloropropene. J. Agric. Food Chem. 2003, 51, 3401-3409. [CrossRef]

30. Yates, S.R.; Gan, J.; Papiernik, S.K.; Dungan, R.S.; Wang, D. Reducing Fumigant Emissions After Soil Application. Phytopathology 2002, 92, 1344-1348. [CrossRef]

31. Long, G. The method of disinfection of facility soil with drugs. Hum. Agricuture 2008, 18.

32. Hale, S.; Mirusso, J.; Jakob, L.; Oleszczuk, P.; Hartnik, T.; Henriksen, T.; Okkenhaug, G.; Martinsen, V.; Cornelissen, G. Short-term effect of the soil amendments activated carbon, biochar, and ferric oxyhydroxide on bacteria and invertebrates. Environ. Sci. Technol. 2013, 47, 8674-8683. [CrossRef]

33. Igalavithana, A.; Deshani, A. Agricultural and Environmental Applications of Biochar: Advances and Barriers ॥ The Effects of Biochar Amendment on Soil Fertility; SSSA Special Publication: Madison, WI, USA, 2016.

34. Pasquale, M.; Massimo, R.; Lucia, P.; Barbara, I.; Luigi, M. Improvement of soil solarization through a hybrid system simulating a solar hot water panel. In Proceedings of the International Conference on Sustainable Environment and Agriculture, Addis Ababa, Ethiopia, 13-16 July 2015.

35. Bao, S. Soil and Agricultural Chemistry Analysis; China Agriculture Press: Beijing, China, 2000; pp. 1-24.

36. Huttenhower, C.; Gevers, D.; Knight, R.; Abubucker, S.H.; Badger, J. Structure, function and diversity of the healthy human microbiome. Nature 2012, 486, 207-214.

37. Bokulich, N.A.; Subramanian, S.; Faith, J.J.; Gevers, D.; Gordon, J.I.; Knight, R.; Mills, D.A.; Caporaso, J.G. Quality-filtering vastly improves diversity estimates from Illumina amplicon sequencing. Nat. Methods 2013, 10, 57-59. [CrossRef] [PubMed]

38. Caporaso, J.G.; Kuczynski, J.; Stombaugh, J.; Bittinger, K.; Bushman, F.D.; Costello, E.K.; Fierer, N.; Pena, A.G.; Goodrich, J.K.; Gordon, J.I.; et al. QIIME allows analysis of high-throughput community sequencing data. Nat. Methods 2010, 7, 335-336. [CrossRef] [PubMed]

39. Haas, B.J.; Gevers, D.; Earl, A.M.; Feldgarden, M.; Ward, D.V.; Giannoukos, G.; Ciulla, D.; Tabbaa, D.; Highlander, S.K.; Sodergren, E.J.G.R. Chimeric $16 \mathrm{~S}$ rRNA sequence formation and detection in Sanger and 454-pyrosequenced PCR amplicons. Genome Res. 2011, 21, 494-504. [CrossRef] [PubMed]

40. Quast, C.; Pruesse, E.; Yilmaz, P.; Gerken, J.; Schweer, T.; Yarza, P.; Peplies, J.; Glockner, F.O. The SILVA ribosomal RNA gene database project: Improved data processing and web-based tools. Nucleic Acids Res. 2012, 41, 590-596. [CrossRef]

41. Edgar, R.C. MUSCLE: Multiple sequence alignment with high accuracy and high throughput. Nucleic Acids Res. 2004, 32, 1792-1797. [CrossRef]

42. Lozupone, C.A.; Hamady, M.; Kelley, S.T.; Knight, R. Quantitative and Qualitative $\beta$ Diversity Measures Lead to Different Insights into Factors That Structure Microbial Communities. Appl. Environ. Microbiol. 2007, 73, 1576-1585. [CrossRef]

43. Jiang, X.; Peng, X.; Deng, G.; Sheng, H.; Wang, Y.; Zhou, H.; Tam, N.F.Y. Illumina Sequencing of 16S rRNA Tag Revealed Spatial Variations of Bacterial Communities in a Mangrove Wetland. Microb. Ecol. 2013, 66, 96-104. [CrossRef]

44. Xie, W.; Su, J.; Zhu, Y. Phyllosphere bacterial community of floating macrophytes in paddy soil environments as revealed by illumina high-throughput sequencing. Appl. Environ. Microbiol. 2015, 81, 522-532. [CrossRef]

45. Ibekwe, A.M. Effects of Fumigants on Non-Target Organisms in Soils. Adv. Agron. 2004, 83, 1-35.

46. Rokunuzzaman, M.; Hayakawa, A.; Yamane, S.; Tanaka, S.; Ohnishi, K. Effect of soil disinfection with chemical and biological methods on bacterial communities. Egypt. J. Basic Appl. Sci. 2016, 3, 141-148. [CrossRef] 
47. Louise, F.; Mathis Hjort, H.; Morten Schostag, N.; Anne Dorthe, J.; Regin, R.; Flemming, E.; Paul Henning, K.; Bjarne Westergaard, S.; Carsten Suhr, J. Pesticide Side Effects in an Agricultural Soil Ecosystem as Measured by amoA Expression Quantification and Bacterial Diversity Changes. PLoS ONE 2015, 10, e0126080.

48. Liu, X.; Cheng, X.; Wang, H.; Wang, K.; Qiao, K. Effect of fumigation with 1,3-dichloropropene on soil bacterial communities. Chemosphere 2015, 139, 379-385. [CrossRef] [PubMed]

49. Li, J.; Huang, B.; Wang, Q.; Li, Y.; Fang, W.; Yan, D.; Guo, M.; Cao, A. Effect of fumigation with chloropicrin on soil bacterial communities and genes encoding key enzymes involved in nitrogen cycling. Environ. Pollut. 2017, 227, 534-542. [CrossRef] [PubMed]

50. Fang, W.; Yan, D.; Wang, B.; Huang, B.; Wang, X.; Liu, J.; Liu, X.; Li, Y.; Ouyang, C.; Wang, Q. Responses of Nitrogen-Cycling Microorganisms to Dazomet Fumigation. Front. Microbiol. 2018, 9, 2529. [CrossRef]

51. Eo, J.; Park, K. Effects of dazomet on soil organisms and recolonisation of fumigated soil. Pedobiologia 2014, 57, 147-154. [CrossRef]

52. Li, K.; Shi, J.; Han, Y.; Xu, C.; Han, H. Enhanced anaerobic degradation of quinoline, pyriding, and indole with polyurethane (PU), Fe3O4 @PU, powdered activated carbon (PAC), Fe(OH)3 @PAC, biochar, and $\mathrm{Fe}(\mathrm{OH}) 3$ @biochar and analysis of microbial succession in different reactors. Bioresour. Technol. 2019, 291, 121866. [CrossRef]

53. Huang, B.; Yan, D.; Wang, Q.; Fang, W.; Cao, A. Effects of dazomet fumigation on soil phosphorus and the composition of phoD-harboring microbial community. J. Agric. Food Chem. 2020, 68, 5049-5058. [CrossRef]

54. Mao, L.; Yan, D.; Wang, Q.; Li, Y.; Ouyang, C.; Liu, P.; Shen, J.; Guo, M.; Cao, A. Evaluation of the Combination of Dimethyl Disulfide and Dazomet as an Efficient Methyl Bromide Alternative for Cucumber Production in China. J. Agric. Food Chem. 2014, 62, 4864-4869. [CrossRef]

55. Chan, K.Y.; Zwieten, L.V.; Meszaros, I.; Downie, A.; Joseph, S. Agronomic values of greenwaste biochar as a soil amendment. Soil Res. 2007, 45, 629-634. [CrossRef]

56. Isobe, K.; Fujii, H.; Tsuboki, Y. Effect of Charcoal on the Yield of Sweet Potato. Jpn. J. Crop Sci. 1996, 65, 453-459. [CrossRef]

57. Kishimoto, S.; Sugiura, G. Charcoala as a soil conditioner. Int. Achieve Future 1985, 5, 12-23.

58. Topoliantz, S.; Ponge, J.; Ballof, S. Manioc peel and charcoal: A potential organic amendment for sustainable soil fertility in the tropics. Biol. Fertil. Soils 2005, 41, 15-21. [CrossRef]

59. Iswaran, V.; Jauhri, K.S.; Sen, A. Effect of charcoal, coal and peat on the yield of moong, soybean and pea. Soil Biol. Biochem. 1980, 12, 191-192. [CrossRef]

60. Mizuta, K.; Matsumoto, T.; Hatate, Y.; Nishihara, K.; Nakanishi, T. Removal of nitrate-nitrogen from drinking water using bamboo powder charcoal. Bioresour. Technol. 2004, 95, 255-257. [CrossRef]

61. Gao, S. Application Technology of Activated Carbon; Southeast University Press: Nanjing, China, 2002; ISBN 7-81050-869-5.

62. Sun, Y.; Jiang, G.; Liu, J.; Zhang, W.; Tang, Z. Effects of Continuous Cropping Tomato for Processing on Soil Enzyme Activities and Microbial Flora. Acta Ecol. Sin. 2010, 227-235.

63. Liu, J.; Sui, Y.; Yu, Z.; Shi, Y.; Chu, H.; Jin, J.; Liu, X.; Wang, G. High throughput sequencing analysis of biogeographical distribution of bacterial communities in the black soils of northeast China. Soil Biol. Biochem. 2014, 70, 113-122. [CrossRef]

64. Fierer, N.; Schimel, J.P.; Holden, P.A. Variations in microbial community composition through two soil depth profiles. Soil Biol. Biochem. 2003, 35, 167-176. [CrossRef]

65. Marschner, P.; Yang, C.H.; Lieberei, R.; Crowley, D.E. Soil and plant specific effects on bacterial community composition in the rhizosphere. Soil Biol. Biochem. 2001, 33, 1437-1445. [CrossRef]

66. Beauregard, M.S.; Hamel, C.; Atul-Nayyar; St-Arnaud, M. Long-Term Phosphorus Fertilization Impacts Soil Fungal and Bacterial Diversity but not AM Fungal Community in Alfalfa. Microb. Ecol. 2010, 59, 379-389. [CrossRef]

67. Yao, Q.; Liu, J.; Yu, Z.; Li, Y.; Jin, J.; Liu, X.; Wang, G. Changes of bacterial community compositions after three years of biochar application in a black soil of northeast China. Appl. Soil Ecol. 2017, 113, 11-21. [CrossRef]

68. Staddon, W.J.; Trevors, J.T.; Duchesne, L.C.; Colombo, C.A. Soil microbial diversity and community structure across a climatic gradient in western Canada. Biodivers. Conserv. 1998, 7, 1081-1092. [CrossRef]

69. Alvey, S.; Yang, C.; Buerkert, A.; Crowley, D.E. Cereal/legume rotation effects on rhizosphere bacterial community structure in west african soils. Biol. Fertil. Soils 2003, 37, 73-82. [CrossRef] 
70. Zak, D.R.; Holmes, W.E.; White, D.C.; Peacock, A.D.; Tilman, D. Plant diversity, soil microbial communities, and ecosystem function: Are there any links? Ecology 2003, 84, 2042-2050. [CrossRef]

71. Papatheodorou, E.M.; Argyropoulou, M.; Stamou, G.P. The effects of large- and small-scale differences in soil temperature and moisture on bacterial functional diversity and the community of bacterivorous nematodes. Appl. Soil Ecol. 2004, 25, 37-49. [CrossRef]

72. Sigler, W.V.; Turco, R.F. The impact of chlorothalonil application on soil bacterial and fungal populations as assessed by denaturing gradient gel electrophoresis. Appl. Soil Ecol. 2002, 21, 107-118. [CrossRef]

Publisher's Note: MDPI stays neutral with regard to jurisdictional claims in published maps and institutional affiliations.

(C) 2020 by the authors. Licensee MDPI, Basel, Switzerland. This article is an open access article distributed under the terms and conditions of the Creative Commons Attribution (CC BY) license (http://creativecommons.org/licenses/by/4.0/). 